\title{
METAL ACCUMULATION AND PIGMENT STRESS OF AQUATIC BRYOPHYTES FROM THE RIVER EUME, GALICIA (NW SPAIN)
}

\author{
López, J. and Carballeira, A. \\ Area de Ecología, Facultad de Biología, Universidad de Santiago de Compostela, 15071 Santiago de Compostela, Spain.
}

Keywords: Aquatic bryophytes, Metals, Pigment, Contamianction.

\begin{abstract}
A study is made of metal accumulation ( $\mathrm{Cu}, \mathrm{Cd}, \mathrm{Zn}, \mathrm{Pb}, \mathrm{Ni}, \mathrm{Mn}$ and $\mathrm{Fe}$ ) and pigment stress caused in the following bryophytes: Fontinalis antipyretica Hedw., Rhynchostegium riparioides (Hedw.) Card., Fissidens polyphyllus Wils. and Scapania undulata (L.) Dum., collected from the river Eume, Galicia (NW Spain). This river bears a gross metal pollution due to an open cast mine of a termal power station set up on its basin.

S. undulata and $F$. polyphyllus were the species with the maximum and minimum accumulative efflciency respectively. Ni showed an exceptional mean value, higher than any published value. Correlations between metal concentrations in water-bryophytes were very low being significant only for $\mathrm{Zn}$ and $\mathrm{Mn}$.

The damaging effects of heavy metals on bryophytes can be observed in the high correlations found between pigment stress (ratio D665/D665a) and metal concentration. The evaluation of water quality by means of the calculation of contamination factors is also discussed.
\end{abstract}

\section{INTRODUCTION}

The particular morphology and physiology of aquatic bryophytes allow them to be hyperaccumulators of heavy metals in water. This capacity has led to numerous studies (MOUVET, 1979, 1980 and 1984a; EMPAIN et al., 1980; SAY et al., 1981; WEHR et al., 1981; WHITTON et al., 1981; JONES et al., 1985; MOUVET et al., 1986; ANDRE \& LASCOMBE, 1987; MASON \& MACDONALD, 1988). Metal relationship bryophyte-water has also been widely studied (WHITTON et al., 1982; SAY \& WHITTON, 1983; WEHR \& WHITTON, 1983; EMPAIN, 1988) as well as the relation of accumulation efficiency among different species (JONES, 1985; KELLY \& WHITTON, 1989). Many of these papers have shown that aquatic bryophytes have higher concentration factors for metals than sediments and phanerogams (DIETZ, 1973).

The studies on the relation bryophyte-water have been performed mainly with total and filtrable metal, being rare the studies about the influence of the chemical speciation of metals on the bioaccumulation (MOUVET, 1984b). Heavy metal pollution specially damages plant leaves. Chloroplasts and mitochondria are the most damaged organelles, which involves the alteration of the photosynthetic pigments and the decrease of chlorophyll biosynthesis (BARCELO \& POSCHENRIEDER, 1989 and 1990). The consequences of metal pollution on the biology of aquatic bryophytes, even knowing their importance as primary producers in the aquatic ecosystems, have not been as studied as their accumulation efficiency (MCCLEAN \& JONES, 1975; EMPAIN, 1977; SATAKE et al., 1989).

The objective of this study is to compare the efficiency of metal amplification among different species, and the relationship between metal concentration in bryophytes and different chemical forms of metal in water. At the same time we try to analyse how plant physiology is affected by metal contamination. This analysis is based on the characterization of pigment responses to pollution. Finally, we try to evaluate the degree of metal pollution in the study area, by means of metal concentrations in bryophytes.

\section{MATERIALS AND METHODS}

This study was made in the basin of river Eume (Galicia NW Spain). This area bears an important mining and industrial 
activity due to a termal power station; the river does not show a serious organic pollution. Samples were taken from twelve stations; four of them in undisturbed tributaries. The remaining stations were distributed along the stream, four sites being down stream from the power station (Fig. 1).
(Nesslerization method), FRP (filtrable reactive phosphate, by Ascorbic Acid method), COD (Consumption of $\mathrm{KMnO}_{4}, 10$ $\min$ ), $\mathrm{Cu}, \mathrm{Zn}, \mathrm{Cd}$ and $\mathrm{Pb}$ (polarographyc method, separating in each sample the fractions: free in solution, complexed in solution, total in solution, particulate metal and total metal) and

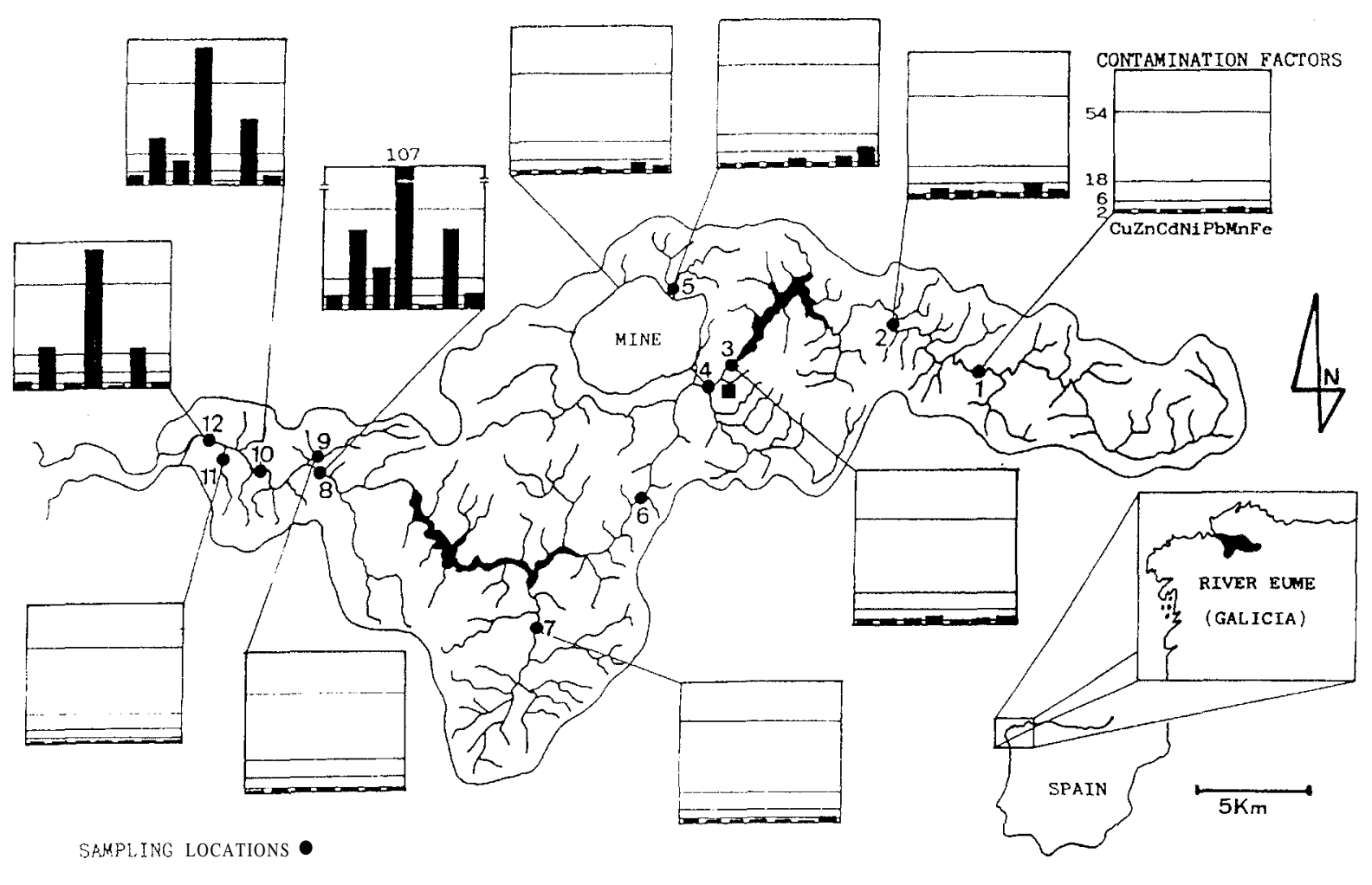

TERMAL POWER STATION.

FIGURE 1. Mean contamination factors for each metal in the aquatic bryophytes in river Eume catchment.

Wherever possible samples were collected of the following species: F. antipyretica Hedw., R. riparioides (Hedw.) Card., F. polyphyllus Wils. and S. undulata (L.) Dum. Samples were taken from various locations within each sampling station (comprising a $100 \mathrm{~m}$ stretch of river), in areas of rapid flow, below the low water level at depths of less than $60 \mathrm{~cm}$.

Prior to briophyte sampling four water samples were taken (once a week) in the stations: 1, 3, 5, 6, 7, 8, 10, 11 y 12 (Fig. 1) for physical and chemical analysis by conventional methods (Standard Methods, 1985). Water samples were collected in 21 polyethylene beakers. Temperature, $\mathrm{pH}$, conductivity and oxygen were determined in situ; $\mathrm{Cl}^{-}$(Argentometric method), $\mathrm{SO}_{4}{ }^{2-}$ (Turbidimetric method), Ca (EDTA Titrimetric method), $\mathrm{NO}_{3}^{-}$(Ultraviolet Spectrophotometric method), $\mathrm{NO}_{2}{ }^{-}$(Sulfanilic acid + NED, Spectrophotometric method), $\mathrm{NH}_{4}{ }^{+}$ filtrable (Teflon filter) Mn (Formaldoxime method) and Fe (Phenanthroline method) were determined in the laboratory within 48 hours, stored in the dark at $4{ }^{\circ} \mathrm{C}$.

Bryophyte samples were washed several times in stream water to remove attached particles. They were stored in refrigerated boxes $(5 \pm 2$ "C) and brought back to the laboratory where the terminal $2 \mathrm{~cm}$. tips were removed to give a fresh weight of aproximately $10 \mathrm{~g}$. The tips were thoroughly washed with deionized water for two hours $(20 \pm 2$ "C) dried to constant weight at $45 \pm 5^{\circ} \mathrm{C}$ and then ground in an agate mill.

Total digestion of organic matter and extraction of metals from each sample $(250-300 \mathrm{mg})$ was carried out using nitric acid (10 ml supra-pur quality) in Teflon vessels with pressure valves placed in a microwave oven. The mineralization process comprised predigestion for $30 \mathrm{~min}$ at atmospheric pressure 
followed by $2 \mathrm{~min} 30 \mathrm{~s}$ at $750 \mathrm{Watts}$ and $20 \mathrm{~min}$ at 300 Watts; samples were then cooled and brought back to atmospheric pressure. This process was repeated three times. Finally, the extract was made up to $50 \mathrm{ml}$ with de-ionized water and purified by filtration $(0.45 \mu \mathrm{M}$ Teflon membrane Milipore filters).

Determination of metal concentration (three replicates per moss sample) was done using flame atomic absortion spectrophotometry (Perkin Elmer 2100). Metals analysed and their detection limits ( $\mathrm{pg} \mathrm{g}^{\prime}$ ) were: cadmium (0.008), zinc, copper, iron, nickel and manganese (0.01) and lead (0.02). As a control for the whole process (from extraction to determination) samples of certified reference material (BCR $\mathrm{N}^{\circ} 61$ : Rhynchostegium riparioides) were also analyzed. The recovery was higher than $95 \%$ for $\mathrm{Cu}, \mathrm{Ni}, \mathrm{Pb}$ and $\mathrm{Zn}$; and higher than $90 \%$ for Fe and Mn.

The determination of the physiological stress degree in the plant was carried out by studying the pigment changes generated in the different sFies along the river. For pigment analysis the samples were washed and tips pigments were extracted with $90 \%$ acetone during one hour at $20 \pm 2{ }^{\circ} \mathrm{C}$ in darkness. The homogenates obtained were centrifuged at $1500 \mathrm{rpm}$ for three minutes. Then, after the spectrophotometric reading of absor-
bance-(Milton Roy Spectronic 3000 Array), we calculated the following pigments and pigment ratios: Chlorophyll a (VOLLENWEIDER, 1974), Chlorophyll b (LORENZEN, 1967), Chlorophyll a/b, D430/D665 (absorbance at 430 $\mathrm{nm} / \mathrm{absorbance}$ at $665 \mathrm{~nm}$ ) and D665/D665a (absorbance at $665 \mathrm{~nm} /$ absorbance at $665 \mathrm{~nm}$ after the addition of $30 \mathrm{pl}$ of $1 \mathrm{~N}$ $\mathrm{HCl}$ to $3 \mathrm{ml}$ of pigment extract) (MARGALEF, 1983; MOUVET, 1984; PEÑUELAS, 1985; MARTÍNEZ \& SÁNCHEZ, 1987; ZAPATA, 1988). Pigment contents are referred to plant dry weight.

\section{RESULTS}

\section{Metal concentration(relation water-bryophytes).}

Physico-chemical characteristics of water are summarized in Table 1. Table 2 shows metal concentrations in bryophyte apical tips. F. antipyretica had the highest concentrations for all metals with the exception of $\mathrm{Pb}$ and $\mathrm{Fe}$. Both metals got the highest values in $S$. undulata. This latter was the only species studied that disappeared from the stations below the lignite mine.

TABLE 1. Physicochemical characteristics of water in the sampling sites. FRP: filtrable reactive phosphate, FS: free in solution, TS: total in solution, P: particulate, SD: standard deviation, X: mean. Number of samples $=9$.

\begin{tabular}{|c|c|c|c|c|c|}
\hline Variable & Unit & Min. & Max. & $\mathbf{X}$ & SD \\
\hline $\mathrm{pH}$ & 6.0 & 7.1 & 6.7 & 0.3 & \\
\hline Conductivity & $\mu S \mathrm{~cm} \cdot^{\prime}$ & 43 & 158 & 98 & 52 \\
\hline $\mathrm{Ca}$ & $\mathrm{mgl}^{-1}$ & 1.9 & 17.6 & 8.3 & 6.8 \\
\hline $\mathrm{O}_{2}$ & $\%$ Sat & 99 & 104 & 101 & 1.5 \\
\hline COD & $m g l^{-1}$ & 1.3 & 3.5 & 2.2 & 0.7 \\
\hline $\mathrm{NO}_{3}$ & $\mathrm{mgl}^{-1}$ & 0.9 & 2.3 & 1.4 & 0.4 \\
\hline $\mathrm{NO}_{2}^{2}$ & $\mathrm{mgl}^{-1}$ & 0.004 & 0.016 & 0.01 & 0.004 \\
\hline $\mathrm{NH}$, & $\mathrm{mgl}^{\perp}$ & 0.014 & 0.111 & 0.053 & 0.04 \\
\hline FRP & $\mathrm{mgl}^{-1}$ & 0.002 & 0.021 & 0.016 & 0.006 \\
\hline $\mathrm{Cl}$ & $\mathrm{mgl}^{-1}$ & 10.4 & 15.3 & 13.0 & 1.8 \\
\hline $\mathrm{SO}_{4}{ }^{2-}$ & $\mathrm{mg} 1^{-1}$ & 1.6 & 42.6 & 19.9 & 18.8 \\
\hline $\mathrm{Zn} \mathrm{FS}$ & $\mu g 1^{-1}$ & 0.08 & 4.47 & 1.69 & 2.03 \\
\hline $\mathrm{TS}$ & $\mu \mathrm{g} 1^{-1}$ & 0.88 & 6.23 & 3.44 & 2.18 \\
\hline $\mathrm{P}$ & $\mu \mathrm{gl}{ }^{1}$ & 0.04 & 3.51 & 1.34 & 1.23 \\
\hline $\mathrm{Cd} \mathrm{TS}$ & $\mu \mathrm{gl}^{-1}$ & 0.028 & 00.69 & 0.028 & 0.019 \\
\hline $\mathrm{P}$ & $\mu g 1^{1}$ & 0.070 & 0.298 & 0.183 & 0.077 \\
\hline $\mathrm{Pb} F S$ & $\left.\mu g\right|^{-1}$ & 0.10 & 30.40 & 8.20 & 12.12 \\
\hline $\mathrm{TS}$ & $\mu \mathrm{g} 1^{1}$ & 1.13 & 31.57 & 9.58 & 12.13 \\
\hline $\mathrm{P}$ & $\mu \mathrm{g} 1^{-1}$ & 0.63 & 26.23 & 13.11 & 12.08 \\
\hline $\mathrm{Cu} F \mathrm{FS}$ & $\mu \mathrm{gl}^{-1}$ & 0.31 & 1.46 & 0.67 & 0.42 \\
\hline $\mathrm{TS}$ & $\mu \mathrm{gl} 1^{-1}$ & 0.67 & 1.56 & 1.00 & 0.33 \\
\hline $\mathrm{P}$ & $\left.\mu g\right|^{-1}$ & 0.03 & 0.26 & 0.10 & 0.09 \\
\hline Mn TS & $\left.\mu g\right|^{-1}$ & 38 & 201 & 111 & 66 \\
\hline $\mathrm{Fe} T S$ & $\operatorname{\mu g} 1^{-1}$ & 3 & 184 & 68 & 77 \\
\hline
\end{tabular}



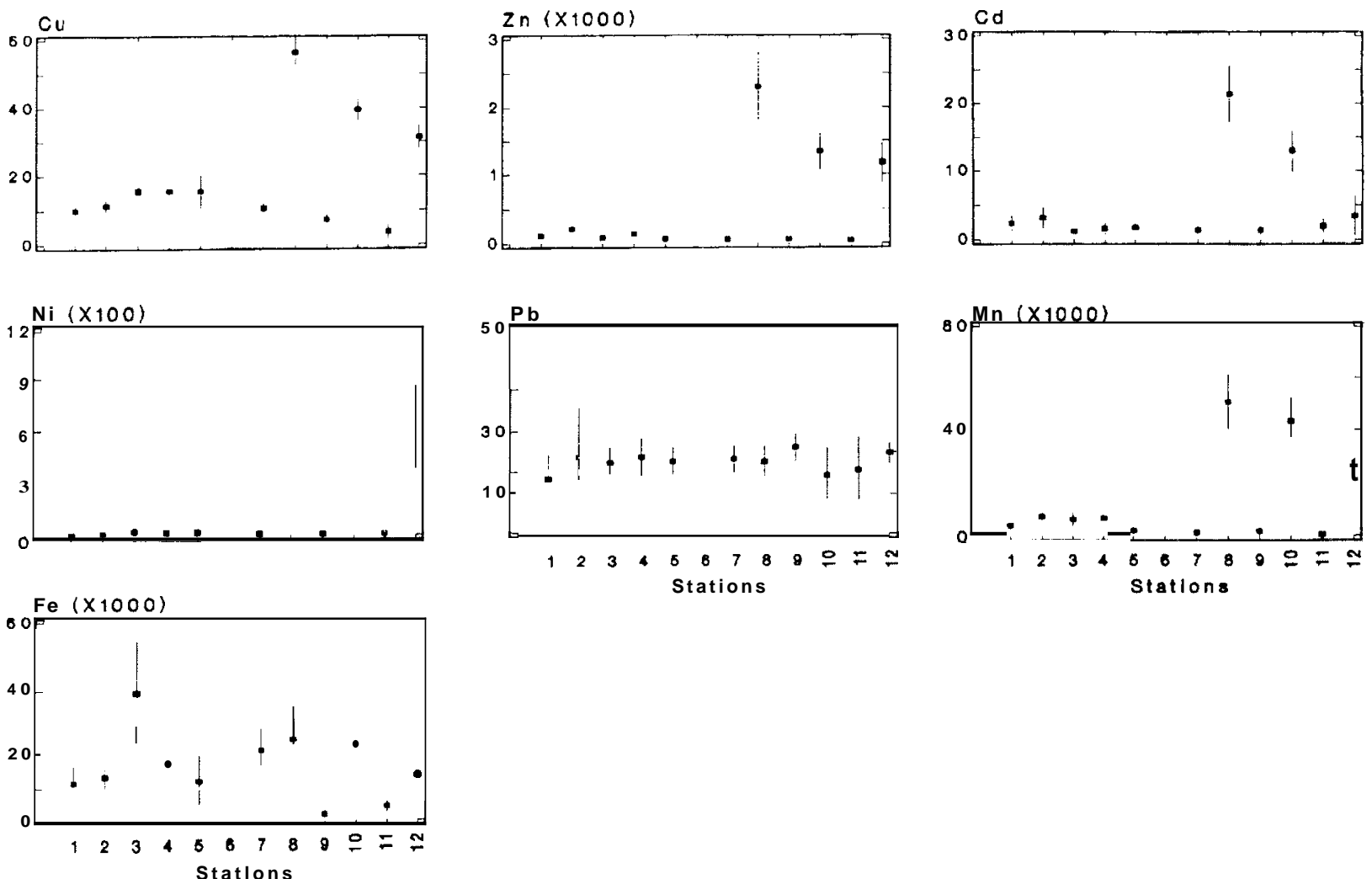

FIGURE 2. Development of mean metal concentrations ( $\mu \mathrm{gg}-1)$ on the pooled bryophytes apical tips and confidence intervals $(95 \%)$ in river Eume

Mean metal concentrations in shoot tips and their confidence intervals (95\%) along the river are given in Fig. 2. Only $\mathrm{Pb}$ values remain regular, whereas there is a significant increase of the other metals concentrations at the stations 8,10 and 12 , placed below the mine. It is significant the absence of any bryophyte at station 6 which is placed just below the mine.

$(\%)$

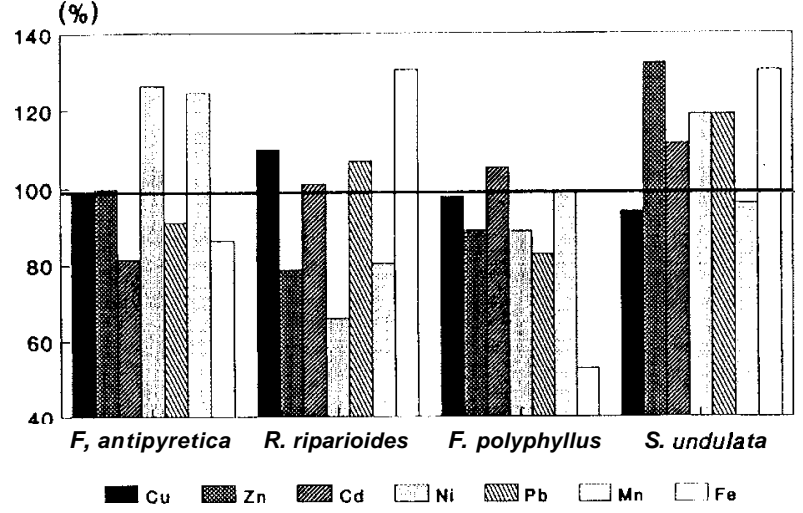

FIGURE 3. Mean interspecific accumulation or relationship between metal concentration in a species aid mean concentration of that metal in all the species (\%).
To analyse the accumulation capacity of the different species, we studied the interspecific mean accumulation or relation between metal concentration in one species and the average concentration of that metal in all the species $(\%)$. The maximun concentrations of all metals were found in samples of S. undulata, except in the cas of $\mathrm{Cu}$ and $\mathrm{Mn}$ (below 100\%), whereas the lowest values for all metals were found in F. polyphyllus samples exceeding the average only for Cd (Fig. 2). The relationship between the different forms of metal in water and metal in plant are given in Table 3. Correlations were significant only for $\mathrm{Zn}$ and $\mathrm{Mn}$.

\section{Pigment stress (relation stress-metal concentration)}

Table 4 shows the values of chorophyll concentrations and pigment ratios of each species studied. F. antipyretica presented the largest ranges of variation to any ratio, whereas S. undulata presented the lowest ranges. The measurement of the ratio D665/D665a is independent from the extraction errors and pigment predicted equations are not needed, so that this ratio is the most suitable to assess the stress of aquatic bryophytes (LOPEZ 
TABLE 3. Main Pearson correlation coefficients (r) among metal concentrations bryophytes-water (FS: free in solution, C: complexed, TS: total in solution, P: particulated, T: total). ${ }^{*} p<0.05$

\begin{tabular}{|c|c|c|c|c|c|}
\hline \multicolumn{2}{|c|}{ Element } & $\begin{array}{c}\text { Fontinalis } \\
\text { antipyretica }\end{array}$ & $\begin{array}{l}\text { Rhynchostegium } \\
\text { riparioides }\end{array}$ & $\begin{array}{c}\text { Fissidens } \\
\text { polyphyllus }\end{array}$ & $\begin{array}{l}\text { Scapania } \\
\text { undulata }\end{array}$ \\
\hline $\mathrm{Zn}$ & FS & $0.87^{*}$ & $0.87^{*}$ & 0.82 & $0.87^{*}$ \\
\hline & $\mathrm{C}$ & 0.45 & 0.46 & 0.45 & 0.46 \\
\hline & TS & $0.88 *$ & $0.89 *$ & $0.84^{*}$ & $0.88^{*}$ \\
\hline & $\mathrm{P}$ & 0.47 & 0.46 & 0.48 & 0.47 \\
\hline & $\mathrm{T}$ & $0.94^{*}$ & $0.94^{*}$ & $0.91 *$ & $0.94^{*}$ \\
\hline $\mathrm{Cu}$ & $\mathrm{P}$ & 0.40 & 0.37 & 0.40 & 0.36 \\
\hline $\mathrm{Pb}$ & FS & - & - & & 0.58 \\
\hline & $\mathrm{C}$ & 0.83 & & & 0.66 \\
\hline & TS & 0.20 & & - & 0.67 \\
\hline & $\mathbf{P}$ & & & 0.41 & - \\
\hline & $\mathbf{T}$ & 0.14 & - & 0.62 & - \\
\hline $\mathrm{Mn}$ & TS & $0.84 *$ & $0.84^{*}$ & $0.84^{*}$ & $0.87^{*}$ \\
\hline & TS & 0.33 & 0.30 & $0.84 *$ & 0.39 \\
\hline
\end{tabular}

TABLE 4. Basic statistics of pigment ratios studied in the different species. X: mean, SD: standard deviation

\begin{tabular}{llccc}
\hline Index & Fontinalis & $\begin{array}{c}\text { Rhynchostegium } \\
\text { antipyretica }\end{array}$ & Fissidens & $\begin{array}{c}\text { Scapania } \\
\text { undulata }\end{array}$ \\
\hline D665/D665alyphyllus
\end{tabular}

TABLE 5. Pearson correlation coefficient (r) between the ratio D665/D665a and metal concentration in aquatic bryophytes. ${ }^{*} p<0.05 ;{ }^{* *} \mathrm{p}<0.01$

\begin{tabular}{|c|c|c|c|c|}
\hline & $\begin{array}{c}\text { Fontinalis } \\
\text { antipyretica }\end{array}$ & $\begin{array}{c}\text { Rhynchostegium } \\
\text { riparioides }\end{array}$ & $\begin{array}{c}\text { Fissidens } \\
\text { polyphyllus }\end{array}$ & $\begin{array}{l}\text { Scapania } \\
\text { undulata }\end{array}$ \\
\hline $\mathrm{Cu}$ & $-0.82 * *$ & $* 0.66$ & $-0.86 * *$ & -0.34 \\
\hline $\mathrm{Zn}$ & $-0.80 * *$ & $-0.72^{*}$ & $-0.82 * *$ & -0.42 \\
\hline $\mathrm{Cd}$ & 0.67 & -0.63 & $-0.83 * *$ & -0.14 \\
\hline $\mathrm{Ni}$ & $-0.83^{* *}$ & -0.71 & $-0.75^{*}$ & -0.22 \\
\hline $\mathrm{Pb}$ & -0.12 & -0.34 & 0.27 & -0.49 \\
\hline Mn & $-0.82 * *$ & $-0.73^{*}$ & $-0.86^{* *}$ & -0.74 \\
\hline $\mathrm{Fe}$ & -0.34 & -0.63 & $-0.89 * *$ & -0.74 \\
\hline
\end{tabular}

\& CARBALLEIRA, 1990). Table 5 shows the correlation coefficients between the ratio D665/D665a and the metal concentration in each species, observing significant correlations in $\mathrm{F}$. antipyretica and $F$. polyphyllus for $\mathrm{Cu}, \mathrm{Zn}, \mathrm{Cd}, \mathrm{Ni}$ and $\mathrm{Mn}$.

\section{Evaluation of metal pollution}

Contamination factors were calculated (ANDRE \& LASCOMBE, 1987) as a multiplication factors in relation to back- 
ground values. Reference values were extracted from the stations with the lowest metal pollution levels (Table 6). If we compare these values with those reported by MOUVET et al. (1986), we observe that they are the same for $\mathrm{Cd}$ and $\mathrm{Pb}$; lower for $\mathrm{Cu}, \mathrm{Zn}$ and $\mathrm{Ni}$ and higher for $\mathrm{Fe}$ and $\mathrm{Mn}$. On the other hand if we compare the same values with those reported by LOPEZ et al. (1990) for Galician rivers (NW Spain) we observe that they are the same for $\mathrm{Cd}$, lower for $\mathrm{Cu}, \mathrm{Zn}, \mathrm{Ni}$ and $\mathrm{Mn}$ and higher for Fe (Table 6). Mean values of contamination factors for each metal in river Eume are shown in Fig. 1.

TABLE 6. Reference values for metal concentration in aquatic bryophytes $\left(\mu \mathrm{gg}{ }^{\mathrm{l}}\right)$.

\begin{tabular}{lrrrrrrr}
\hline & Cu & Zn & Cd & Ni & Pb & Mn & Fe \\
\hline River Eume & 9 & 56 & 1 & 9 & 20 & 1200 & 4000 \\
Mouvet er al. $(1986)$ & 19 & 200 & 1 & 20 & 19 & 600 & 3000 \\
Lónez et al. $(1990)$ & 15 & 150 & 1 & 30 & 15 & 2000 & 3000 \\
\hline
\end{tabular}

\section{DISCUSSION}

On the basis of our analysis of water, we distinguish three different river stretches: an upper zone (up to the termal power station), with good quality water and low mineralization; an intermediate zone with low quality water due to mining discharges from the power station, here we find the highest concentrations of $\mathrm{Ca}, \mathrm{SO}_{4}{ }^{2}, \mathrm{Zn}, \mathrm{Pb}, \mathrm{Cu}, \mathrm{Mn}$ and $\mathrm{Fe}$ (Table 1); and a lower zone with intermediate concentrations.

\section{Metal concentration}

Maximum metal levels found in the bryophytes from the river Eume were compared with maximum levels found in bibliography. Only a few papers refer to a number of samples large enough to consider the data significant: WARD (1977), BURTON (1986), MOUVET et al. (1986), ANDRE \& LASCOMBE (1987) and EMPAIN (1988).

TABLE 2. Descriptive statistics for metal concentration $\left(\mu \mathrm{g} \mathrm{g}^{\prime}\right)$ in aquatic bryophytes apical tips. SD: standard deviation, X: mean, N: number of samples.

\begin{tabular}{|c|c|c|c|c|c|}
\hline & & $\begin{array}{c}\text { Fontinalis } \\
\text { antipyretica } \\
\quad \mathrm{N}=10\end{array}$ & $\begin{array}{c}\text { Rhynchostegium } \\
\text { riparioides } \\
\mathbf{N}=8\end{array}$ & $\begin{array}{c}\text { Fissidens } \\
\text { polyphyllus } \\
\mathrm{N}=9\end{array}$ & $\begin{array}{c}\text { Scapania } \\
\text { undulata } \\
\quad \mathrm{N}=7\end{array}$ \\
\hline \multirow[t]{4}{*}{$\mathrm{Cu}$} & X & 21 & 16 & 18 & 10 \\
\hline & Min & 4 & 6 & 7 & 4 \\
\hline & Max & 52 & 45 & 40 & 18 \\
\hline & $\mathrm{SD}$ & 14 & 12 & 11 & 5 \\
\hline \multirow[t]{4}{*}{$\mathrm{Zn}$} & $\mathrm{X}$ & 603 & 225 & 368 & 112 \\
\hline & Min & 30 & 51 & 21 & 43 \\
\hline & Max & 2353 & 935 & 1400 & 247 \\
\hline & SD & 786 & 276 & 479 & 66 \\
\hline \multirow[t]{4}{*}{$\mathrm{Cd}$} & $\mathbf{X}$ & 6.6 & 3.6 & 4.2 & 1.9 \\
\hline & Min & $<1.4$ & $<1.4$ & 1.4 & $<1.4$ \\
\hline & Max & 19.8 & 8.6 & 11.8 & 2.8 \\
\hline & $\mathrm{SD}$ & 7.6 & 2.8 & 3.5 & 0.7 \\
\hline \multirow[t]{4}{*}{$\mathrm{Ni}$} & $\mathrm{X}$ & 332 & 71 & 153 & 31 \\
\hline & Min & 3 & 2 & 1 & 18 \\
\hline & Max & 1134 & 417 & 590 & 61 \\
\hline & $\mathrm{SD}$ & 450 & 134 & 203 & 15 \\
\hline \multirow[t]{4}{*}{ PB } & $X$ & 16 & 20 & 19 & 22 \\
\hline & Min & 8 & 8 & 8 & 16 \\
\hline & Max & 24 & 24 & 24 & 48 \\
\hline & $\mathrm{SD}$ & 5 & 6 & 8 & 11 \\
\hline \multirow{4}{*}{$\mathrm{Mn}$} & $X$ & 19887 & 7216 & 11585 & 3644 \\
\hline & Min & 426 & 284 & 142 & 142 \\
\hline & Max & 65096 & 31655 & 43779 & 7799 \\
\hline & $\mathrm{SD}$ & 23404 & 9738 & 14815 & 3024 \\
\hline \multirow[t]{4}{*}{$\mathrm{Fe}$} & $\mathrm{X}$ & 15156 & 14623 & 7953 & 18839 \\
\hline & Min & 1717 & 3434 & 1285 & 1718 \\
\hline & Max & 39481 & 24778 & 19595 & 47432 \\
\hline & SD & 10926 & 7757 & 6193 & 14004 \\
\hline
\end{tabular}


It is important to take into account which part of the bryophyte is being analysed. Some authors analyse the whole moss whereas other only analyse the tips (different lengths). Other authors analyse several unidentified species as a whole.

Comparing our specific values (Table 2) with previously published values, only $\mathrm{Zn}$ in F. antipyretica comes near the maximum (2353 versus $2825 \mathrm{ppm}$ ), while $\mathrm{Cu}$ and $\mathrm{Pb}$ stand far from the maximum values indicated. But if we compare our specific values with maximum intervals in literature without identifying species, we exceed them for $\mathrm{Ni}$ and $\mathrm{Mn}$ in $\mathrm{F}$. antipyretica and for $\mathrm{Fe}$ in $\mathrm{S}$. undulata; comparing reference maximum levels with maximum mean in R. Eume (Fig. 2), only Ni shows a higher value (958 versus $362 \mathrm{ppm}$ ); so we conclude that $\mathrm{Ni}$ concentration in R. Eume is not only exceptional quantitatively but also unusual in a wide geographical context. These conclusions cannot be taken strictly, since a maximum value is an uncertain value and therefore not much reliable.

S. undulata showed the greatest accumulative capacity, probably due to the lesser regulation ability of the liverwort versus mosses (MARTÍNEZ \& SÁNCHEZ, 1988). The highest concentrations in this species were reported by JONES (1985) for Ag, As and Sb. On the other hand, F. polyphyllus showed the lowest accumulation capacity, possibly due to its smaller specific surface and photosyntetic tissue versus the other species sampled (LOPEZ and CARBALLEIRA, 1990). R. riparioides and $F$. antipyretica showed an intermediate accumulation capacity.

The relationship bryophytes-water in river Eume was only significant for $\mathrm{Zn}$ (free in solution, total in solution and total) and $\mathrm{Mn}$ (total in solution) in all the bryophytes. The lack of significant correlations may be due to the fact that the relations waterbryophytes can only be established when there are continuous recordings of metal content in water. Metal accumulation in bryophytes is determined by: water chemistry, stream characteristics, space variability (vertical and horizontal) of samples, nature of the source of pollution, metal state and relative concentrations. EMPAIN (1988) found a clear relationship between metal concentration in mosses and alkalinity or $\mathrm{pH}$.

\section{Pigment stress}

This study seems to prove that F. antipyretica was the most tolerant species to pollution, whereas S. undulata was the most sensitive, this is probably due to the fact that the livewort is structurally simpler.

Plants affected by metals show spots on surface, chlorosis and necrosis due to changes in the ultrastructure of chloroplasts which cause inhibition on pigment biosynthesis. At the same time, saccharose transport is also inhibited, some essential ion levels are reduced and the production of phenolics and lignin is increased (BARCELO \& POSCHENRIEDER, 1989 and 1990).

High correlations between D665/D665a ratio and corporal heavy metals (Table 6) in F. antipyretica, B. riparioides and F. polyphyllus, and low correlations in $S$. undulata (this species is absent from polluted stations: $6,8,10$ y 12) prove the negative impact, stimulus of senescence, that chronic heavy metal pollution causes on aquatic bryophytes, which can lead to the death of the plant. $\mathrm{Cu}, \mathrm{Zn}, \mathrm{Cd}, \mathrm{Ni}$ and $\mathrm{Mn}$ were the cause of the physiological stress found in the bryophytes from river Eume.

\section{Evaluation of water quality}

Many papers confirm the great capacity of aquatic bryophytes in biological amplification of metal pollution. However it is easy to find opposite directions in the results (DIETZ, 1973; EMPAIN, 1977; MOUVET, 1980 and WEHR \& WHITTON, $1983 \mathrm{~b}$ ). This is mainly due to the high variability of water samples, which are mostly fortuitous. To solve the problem we made use of contamination factors, using reference values calculated for river Eume and the classification proposed by MOUVET et al. (1986) to evaluate water quality. We found that the classes with pollution exceptional and important for $\mathrm{Ni}$, $\mathrm{Mn}, \mathrm{Zn}$ or $\mathrm{Cd}$ were found at the stations 8, 9 and 12; all them below the termal power station.

These results suggest the efficiency of these methods to evaluate metal pollution, and suggest their use in routine surveys of vigilance and control of contamination.

\section{ACKNOWLEDGEMENTS}

Thanks are due to members of the Departements of Physical-Chemistry of the University of Santiago, for the water Chemical analyses and to Rodolfo Barreiro and Carlos Real for their help with metals analyses of the bryophytes. This study was carried out with funding from the C.O.T.O.P. (Conselleria de Ordenación do Territorio e Obras Públicas, Xunta de Galicia).

\section{REFERENCES}

ANDRE, B. \& C. LASCOMBE, 1987. Comparaison de deux traceurs de la pollution métallique des cours d'eau les sédiments et les bryophytes. Sciences de l'eau 6: 225-247.

BARCELO, J. \& CH. POSCHENRIEDER, 1989. Respuestas de las plantas a la contaminacidn por metales pesados. Investigación y Ciencia July: 54-63. 
BARCELO, J. \& CH. POSCHENRIEDER, 1990. Plant water relations as affected by heavy metal stress: a revieu. Journal of Plant Nutrition 13: 1-37.

BURTON, M. A. S. 1986. Biological Monitoring of Environmental Contaminants (Plants). MARC Report Number 32, Monitoring and Assessment Research Centre, Univ., London.

DIETZ, F. 1973. The enrichment of heavy metals in submerged plants. In: S. M. Jenkins (ed.), Advances in water Pollution Research. Proc. 6th Annu. Conf.: 53-62. Pergamon, Oxford.

EMPAIN, A. 1977. Ecologie des populations bryophytiques aquatiques de la Meuse, de la sambre et de la Somme. relations avec la qualité de eaux, écophysiologie comparée et étudie de la contamination par métaux lourds. Ph. D. thesis, Univ. Liege, Belgium.

EMPAIN, A. 1988. A posteriori detection of heavy-metal pollution of aquatic habitats. In: J. M. Glime (ed.), Methods in bryology. Proc. Bryol. Meth. Workshop: 213-220. Mainz.

EMPAIN, A., J. LAMBINON, C. MOUVET \& R. KIRCHMANN, 1980. Utilisation des bryophytes aquatiques et subaquatiques comme indicateurs biologiques de la qualité des eaux courantes. In: P. Pesson (ed.), La pollution des eaux continentales: 195-223. Paris.

JONES, K. C. 1985. Gold, Silver and other elements in aquatic bryophytes from a mineralised area of North Wales, U.K. Jounal of Geochemical Exploration 24: 237-246.

JONES, K. C., P. J. PETERSON \& B. E. DAVIES, 1985. Silver and other metals in some aquatic bryophytes from streams in the lead mining district of Mic-Wales, Great Britain. Water, Air and Soil Pollution 24: 329-338.

KELLY, M. G. \& B. A. WHI'ITON, 1989. Interspecific differences in $\mathrm{Zn}, \mathrm{Cd}$ and $\mathrm{Pb}$ accumulation by freshwateralgae and bryophytes. Hydrobiologia 175: 1-11.

LOPEZ, J., A. CARBALlEIRA, R. BARREIRO \& C. REAL, 1990. Dependence of background heavy metals content of Fontinalis antipyretica Hedw. on geology in the rivers of Galicia (N.W. Spain). In: J. Barceló (ed.), Environmental contamination, 4th International Conference: 638-640. Barcelona.

LOPEZ, J. \& A. CARBALLEIRA, 1990. A comparative study of pigment contents and response to stress in five species of aquatic bryophytes. Lindbergia 15: 188194.

LORENZEN, C. J. 1976. Determination of clhorophyll and phaeo-pigments spectrophotometric equations. Limnol. Ocean. 12: 343-346.

MARGALEF, R. 1983. Limnologia. Omega, Barcelona.

MARTÍNEZ, J. \& M. SANCHEZ, 1987. Efecto de la contaminacidn orgánica sobre indices de feofitinización en trans- plantes de briófitos acuáticos (río Iregua, La Rioja, España). $I V$ Spanish congress of Limnology: 287-297. Sevilla.

MASON, C. F. \& M. S. MACDONALD, 1988. Metal Contamination in mosses and otter distribution in a rural welsh river receiving mine drainage. Chemosphere 17: 1 159-1 166.

MCCLEAN, R. 0. \& A. K. JONES, 1975. Studies of the tolerance to heavy metals in the flora of the river Ystwyth and Clarach, Wales. Freshwat. Biol. 5: 431-444.

MOUVET, C. 1979. Utilisation des bryophytes aquatiques pour l'étudie de la pollution des cours d'eau par les métaux lourds et les radionucléides. Rev. Biol. Ecol. Méd. VI 3-4: 193 204.

MOUVET, C. 1980. Pollution de l'Ambleve par les métaux lourds en particulier le chrome: dosage dans les eaux et les bryophytes aquatiques. Trib. CEBEDEAU 33:527-538.

MOUVET, C. 1984a. Metaux lourds et mousses aquatiques. Speciation physicochimique, bioaccumulation et toxicit. $P h$. $D$. thesis, Univ. Liege, Belgium.

MOUVET, C. 1984b. Accumulation of Chromium and Copper by the aquatic moss Fontinalis antipyretica L. ex Hedw transplanted in a metal-contaminated river. Enviromental Technology Letters 5: 541-548.

MOUVET, C., E. PATTEE \& P. CORDEBAR, 1986. Utilisation des mousses aquatiques pour I'identification et la localisation précise de sources de pollution métallique multiforme. Acta Oecologica, Oecol. Applic. 7:77-91.

PEÑUELAS, J. 1985. Briofits i Fanerogames com a invasors de les aigues dolces. Distribució, pigments, font de carboni i I'obstacle dels espais aeris. Ph. D. Thesis, Univ. Barcelona, Spain.

SATAKE, K., T. TAKAMATSU, M. SOMA, K. SHIBATA, M. NISHIKAWA, P. J. SAY \& B. A. WHI'ITON, 1989. Lead accumulation and location in the shoots of the aquatic liverwort Scapania undulata (L.) Dum. in stream water at Greenside mine, England. Aquatic Botany 33: 122.

SAY, P. J. \& B. A. WHITTON, 1983. Accumulation of heavy metals by aquatic mosses. 1: Fontinalis antipyretica Hedw. Hydrobiologia 100: 245-260.

SAY, P. J., P. HARDING \& B. A. WHITTON, 1981. Aquatic mosses as monitors of heavy metal contamination in the River Etherow, England. Environ. Pollut., Ser. B 2: 295307.

VOLLENWEIDER, R. A. 1974. A manual on methods for measuring peimary production in aquatic environments. Blackwell, Oxford.

WARD, N. I., R. B. ROBERT \& E. ROBERTS, 1977. Heavy metals in some New Zealand Bryophytes. The Bryologist 80: 304-312. 
WEHR, J. D. \& B. A. WHITTON, 1983. Accumulation of heavy metals by aquatic mosses. 2: Rhynchostegium riparioides. Hydrobiologia 100: 261-284.

WEHR, J. D. \& B. A. WHITTON, 1983. Accumulation of heavy metals by aquatic mosses. 3: Seasonal changes. Hydrobiologia 100: 285-291.

WEHR, J. D., P. J. SAY \& B. A. WHITTON, 1981. Heavy metals in an industrial polluted river, the Team. In: Say, P. J. \& R. A. Whitton (eds.), Heavy metals in Nothern England: environmental and biological aspects: 99-107. Durham.
WHITTON, B. A., N. L. GALE \& B. G. WIXSON, 1981. Chemistry and plant ecology of zinc-rich wastes dominated by blue-green algae. Hydrobiologia 83:331-341.

WHITTON, B. A., P. J. SAY \& B. P. JUPP, 1982. Accumulation of zinc, cadmium and lead by the aquatic liverwort Scapania. Environmental pollution 3: 299-316.

ZAPATA, M. 1988. Estimacidn de clorofila a y sus productos de alteracidn. problemática metodológica y su aplicación a sistemas sedimentarios marinos. Ph. D. Thesis, Univ. Santiago de Compostela, Spain. 